\title{
1968 survey of treponematosis in the Eastern Highlands of New Guinea
}

\author{
M. F. GARNER \\ Serologist, Institute of Clinical Pathology and Medical Research, Lidcombe, Sydney, Australia \\ R. W. HORNABROOK \\ Director, Institute of Human Biology, New Guinea
}

IN 1964 to 1965 we investigated treponemal disease among the inhabitants of the Okapa subdistrict of the Eastern Highlands of New Guinea (Garner and Hornabrook, 1968). No case of active yaws was seen in the population studied, but it was concluded that the evidence of past treponemal disease found on serological testing was due to yaws. The prevalence of the disease in the ten main census units studied varied from 3.9 to 79.2 per cent. In only three census units did the children show serological evidence of treponemal infection. It was felt that the non-infected children and adults who had no relative cross-immunity from yaws were of special interest in this rapidly developing country.

In 1968, one of us (R.W.H.), returned to New Guinea to review Kuru and treponemal infection in the ten census units previously studied. It was decided to include as many children under 15 years of age as possible, as well as those adults whose sera had not been examined in the earlier survey. In addition, sera from people in eight smaller census units were tested.

\section{Material}

The eighteen census units in our present survey (see map) were grouped as follows:

One belonged to the Keigana language group (Afaru); two to the Auyana language group (Auyana and Arora); six to the Gimi language group (Mino, Noveraisa, Misape, Ketabe, Haiyuru, and Takarie); three to the North Fore language group (Opoiyanti, Keyonosa, and Okasa); six to the South Fore language group (Miarasa, Yagareba, Ai, Weya, Orie, and Kaserai).

The Misape, Ketabe, Haiyuru, and Takarie census units are all situated close together at a relatively low altitude, and are on the fringe of the Gimi language group. Some of these census units contain a number of people of mixed language origin, and for this reason and because of its situation the Takarie census unit, which could be regarded as a Fore Village, is included with the Gimi language group. The census units Weya, Orie, and

Received for publication June 12, 1969.

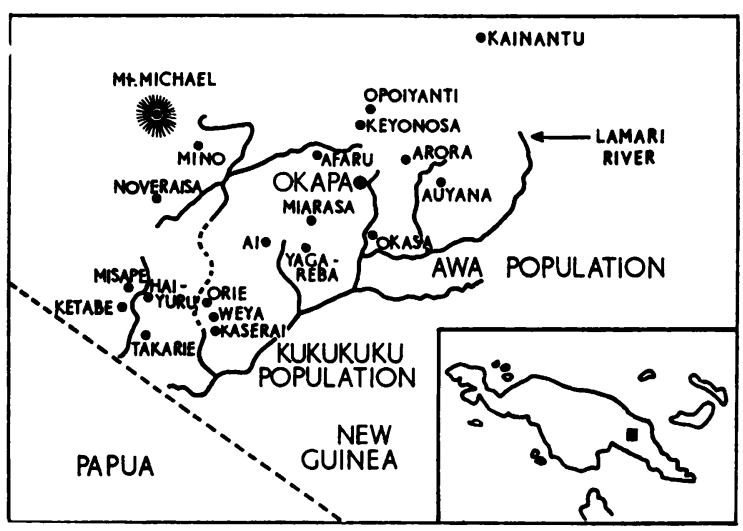

F I G U R E Distribution of Census Units in Okapa

District of the Eastern Highlands of New Guinea

Kaserai also adjoin and are on the fringe of the South Fore language group, again at a low altitude. The number of people tested in each of these census units was small, so they have been grouped together under their appropriate language, i.e. one in the Gimi and one in the South Fore language group.

Every individual in this survey from whom serum was received had a complete physical examination. No cases of active yaws were seen, but a few people had sabre tibiae and saddle noses thought to be due to old yaws infections. (two in each of the Okasa and Auyana census units, and one in each of the Ai, Noveraisa, and Afaru census units). As in the previous survey no clinical evidence of leprosy, malaria, or venereal syphilis was seen. Altogether 546 sera (distributed as shown in Table II) were received from those in the census units under survey. A cardiolipin Wassermann reaction (CWR), a Reiter protein complement-fixation (RPCF) test, a Venereal Disease Research Laboratory (VDRL) test, and a Treponema pallidum immobilization (TPI) test were performed on each specimen of serum. The result of the TPI test was taken to indicate the presence or absence of treponemal infection, i.e. yaws, in those examined. 


\section{Results}

\section{Results in the total group studied}

The prevalence of treponemal disease in the people tested is shown by age group and sex in Table $I$.

Of the 546 sera examined, $99(18 \cdot 1$ per cent.) had reactive results to the TPI test. Serum from 56 (23.2 per cent.) of the 241 males and from 43 (14.1 per cent.) of the 305 females showed reactive TPI test results.

The 203 children ( 82 male and 121 female, aged 0 to 14 years) comprised 37.2 per cent. of the total group. Only eight (3.9 per cent.) of their sera gave reactive results to the TPI test; these included sera from three (3.7 per cent.) male children and from five ( $4 \cdot 1$ per cent.) female children.

It must be stressed that these results reflect the prevalence of infection in the particular group of people tested and not necessarily that in the population as a whole.

As in the previous survey persons aged 15 years and upwards were considered to be adult. There were thus 343 sera from adults ( 159 males and 184 females), and 91 (26.5 per cent.) were reactive to the TPI test; these included 53 ( 33.3 per cent.) from males and 38 (20.7 per cent.) from females. The 343 adults were divided into four age groups, and the prevalence of treponemal infection was found to be highest in those aged 45 to 59 years (40.7 per cent.) and lowest in those aged 15 to 29 years (19.1 per cent.).

\section{Results in relation to census units}

The number and percentage of sera giving reactive results to the TPI test in each census unit are shown by sex in Table II (opposite).

The highest prevalence of treponemal infection was found in the Auyana census units, in which $47 \cdot 3$ per cent. of sera tested gave reactive TPI test results. This was followed by the $\mathrm{Ai}(41.0$ per cent.), the
Opoiyanti (21.4 per cent.), and the grouped Misapio

Ketabe, Haiyuru, and Takarie ( 20.0 per cent.).

The lowest prevalence rates were found in the Noveraisa (2.5 per cent.), Yagareba ( 3.6 per cent.)? and Mino (3.7 per cent.) census units.

The prevalence of treponemal infection was found to be higher in males than in females in all but three census units.

As in the previous survey, the highest prevalences was found in both males and females in the Auyana census unit, sera from 58.1 per cent. of the males anके 39.5 per cent. of the females being reactive to the TPI test. Apart from the Auyana, other units in which $\vec{w}$ more than 20 per cent. of sera gave reactive TPP test results were for males, the grouped Misape, Ketabe, Haiyuru, and Takarie $(46.2$ per cent.), AT (44.0 per cent.), Opoiyanti (28.6 per cent.), Okasহ (23.1 per cent.), Arora (21.4 per cent.), and Afaruv (20.0 per cent.), and for females, the $\mathrm{Ai}(35.7$ per cent. and Keyonosa (21.4 per cent.).

\section{Results in children 0 to 14 years of age}

The eight sera from children which gave reactive TPI test results comprised two out of nineteen fromb the Auyana, two out of five from the Keyonosa, one out of thirty-four from the Okasa, and three out of thirteen from the $\mathrm{Ai}$ census units. No sera were received from children in the Ketabe, Haiyuru, and Takarie census units. In the remaining census unitsnone of the 132 sera from children gave reactive results to the TPI test. No child in any of the census units showed clinical signs of infection.

In discussing yaws in Thailand, the Philippines and Nigeria, Guthe and de Vries (1966) stated that the fluorescent treponemal antibody test should detect nearly all early treponemal infections in के community. The fluorescent treponemal antibody absorption (FTA-ABS) test was performed on the

TABLE I Results of TPI test in relation to age and sex of population studied

\begin{tabular}{|c|c|c|c|c|c|c|c|c|c|c|}
\hline \multirow{3}{*}{$A g e(y r s)$} & & \multirow{3}{*}{$\begin{array}{l}\text { No. of } \\
\text { sera } \\
\text { tested }\end{array}$} & & & \multicolumn{3}{|l|}{ Males } & \multicolumn{3}{|l|}{ Females } \\
\hline & & & \multicolumn{2}{|c|}{ TPI-reactive } & \multirow{3}{*}{$\begin{array}{l}\begin{array}{l}\text { No. of } \\
\text { sera } \\
\text { tested }\end{array} \\
82\end{array}$} & \multicolumn{2}{|c|}{ TPI-reactive } & \multirow{3}{*}{$\begin{array}{l}\begin{array}{l}\text { No. of } \\
\text { sera } \\
\text { tested }\end{array} \\
121\end{array}$} & \multicolumn{2}{|c|}{ TPI-reactive } \\
\hline & & & No. & Per cent. & & No. & Per cent. & & No. & Per cent. \\
\hline Children & $0-14$ & 203 & 8 & 3.9 & & 3 & $3 \cdot 7$ & & 5 & $4 \cdot 1$ \\
\hline \multirow[t]{4}{*}{ Adults } & $15-29$ & 157 & 30 & $19 \cdot 1$ & 55 & 12 & $21 \cdot 8$ & 102 & 18 & $17 \cdot 6$ \\
\hline & $30-44$ & 119 & 35 & $29 \cdot 4$ & 57 & 21 & $36 \cdot 8$ & 62 & 14 & $22 \cdot 6$ \\
\hline & $45-59$ & 59 & 24 & $40 \cdot 7$ & 42 & 19 & $45 \cdot 2$ & 17 & 5 & $29 \cdot 4$ \\
\hline & $60+$ & 8 & 2 & $25 \cdot 0$ & 5 & 1 & $20 \cdot 0$ & 3 & 1 & $33 \cdot 3$ \\
\hline Total & & 343 & 91 & 26.5 & 159 & 53 & $33 \cdot 3$ & 184 & 38 & $20 \cdot 7$ \\
\hline Total sera & & 546 & 99 & $18 \cdot 1$ & 241 & 56 & $23 \cdot 2$ & 305 & 43 & $14 \cdot 1$ \\
\hline
\end{tabular}


TABLE II Number and percentage of TPI-reactive sera in each census unit

\begin{tabular}{|c|c|c|c|c|c|c|c|c|c|}
\hline \multirow{3}{*}{ C:nsus Unit } & \multirow{3}{*}{$\begin{array}{l}\text { No. of } \\
\text { sera } \\
\text { tested }\end{array}$} & \multirow{2}{*}{\multicolumn{2}{|c|}{ TPI-reactive }} & \multicolumn{3}{|l|}{ Males } & \multicolumn{3}{|l|}{ Females } \\
\hline & & & & \multirow{2}{*}{$\begin{array}{l}\text { No. of } \\
\text { sera } \\
\text { tested }\end{array}$} & \multicolumn{2}{|c|}{ TPI-reactive } & \multirow{2}{*}{$\begin{array}{l}\text { No. of } \\
\text { sera } \\
\text { tested }\end{array}$} & \multicolumn{2}{|c|}{ TPI-reactive } \\
\hline & & No. & Per cent. & & No. & Per cent. & & No. & Per cent. \\
\hline Afaru & 67 & 7 & $10 \cdot 4$ & 20 & 4 & $20 \cdot 0$ & 47 & 3 & $6 \cdot 4$ \\
\hline Auyana & 74 & 35 & $47 \cdot 3$ & 31 & 18 & $58 \cdot 1$ & 43 & 17 & $39 \cdot 5$ \\
\hline Arora & 32 & 4 & 12.5 & 14 & 3 & $21 \cdot 4$ & 18 & 1 & $5 \cdot 6$ \\
\hline Mino & 81 & 3 & $3 \cdot 7$ & 41 & 2 & 4.9 & 40 & 1 & $2 \cdot 5$ \\
\hline Noveraisa & 40 & 1 & $2 \cdot 5$ & 21 & 0 & 0 & 19 & 1 & $5 \cdot 3$ \\
\hline Misape, Ketabe, Haiyuru, Takarie & 35 & 7 & $20 \cdot 0$ & 13 & 6 & $46 \cdot 2$ & 22 & 1 & 4.5 \\
\hline Opoiyanti & 28 & 6 & $21 \cdot 4$ & 14 & 4 & $28 \cdot 6$ & 14 & 2 & $14 \cdot 3$ \\
\hline Keyonosa & 21 & 3 & $14 \cdot 3$ & 7 & 0 & 0 & 14 & 3 & $21 \cdot 4$ \\
\hline Okasa & 67 & 13 & $19 \cdot 4$ & 26 & 6 & $23 \cdot 1$ & 41 & 7 & $17 \cdot 1$ \\
\hline Miarasa & 13 & 1 & $7 \cdot 7$ & 7 & 1 & $14 \cdot 3$ & 6 & 0 & 0 \\
\hline Yagareba & 28 & 1 & $3 \cdot 6$ & 12 & 0 & 0 & 16 & 1 & $6 \cdot 3$ \\
\hline $\mathrm{Ai}$ & 39 & 16 & $41 \cdot 0$ & 25 & 11 & $44 \cdot 0$ & 14 & 5 & $35 \cdot 7$ \\
\hline Weya, Orie, Kaserai & 21 & 2 & $9 \cdot 5$ & 10 & 1 & $10 \cdot 0$ & 11 & 1 & $9 \cdot 1$ \\
\hline
\end{tabular}

sera from all children in those census units in which sera from some children had shown reactive TPI test results. In all, 71 sera were tested from children in the Auyana, Keyonosa, Okasa, and $\mathrm{Ai}$ census units. The results of the FTA-ABS and TPI tests agreed in all but one serum, eight being reactive to both FTA-ABS and TPI tests, one reactive to the FTA-ABS test only, and the remaining 62 nonreactive to both tests.

\section{Prevalence of treponemal infection in language groups}

All the census units in the study belonged to five different language groups. The prevalence of treponemal infection, as indicated by the TPI test result, in each of these language groups was Auyana 36.8 per cent., South Fore 19.8 per cent., North Fore 19.0 per cent., Keigana 10.4 per cent., and Gimi $7 \cdot 1$ per cent. (Table III).

If the results from the ten main census units only are considered, in order to compare them with the 1964 to 65 survey results (Table IV, overleaf), the percentage prevalence of treponemal infection was as follows:

$\begin{array}{lcc}\text { Uilit } & 1968 & 1964 \text { to } 65 \\ \text { Auyana } & 47 \cdot 3 & 79 \cdot 2 \\ \text { South Fore } & 22 \cdot 5 & 33 \cdot 3 \\ \text { North Fore } & 19 \cdot 0 & 36 \cdot 7 \\ \text { Keigana } & 10 \cdot 4 & 7 \cdot 6 \\ \text { Gimi } & 3 \cdot 3 & 4 \cdot 1\end{array}$

TABLE III Prevalence of treponemal infection, as indicated by TPI test results, in each language group studied

\begin{tabular}{|c|c|c|c|c|}
\hline \multirow{2}{*}{ Language group } & \multirow{2}{*}{ Census Unit } & \multirow{2}{*}{$\begin{array}{l}\text { No. of } \\
\text { sera } \\
\text { tested }\end{array}$} & \multicolumn{2}{|c|}{ TPI-reactive } \\
\hline & & & No. & Percent \\
\hline Keigana & Afaru & 67 & 7 & $10 \cdot 4$ \\
\hline Auyana & Auyana, Arora & 106 & 39 & $36 \cdot 8$ \\
\hline Gimi & $\begin{array}{l}\text { Mino, Noveraisa, } \\
\text { Misapi, Ketabe, } \\
\text { Haiyuru, Takarie }\end{array}$ & 156 & 11 & $7 \cdot 1$ \\
\hline North Fore & $\begin{array}{l}\text { Opoiyanti, } \\
\text { Keyonosa, } \\
\text { Okasa }\end{array}$ & 116 & 22 & $19 \cdot 0$ \\
\hline South Fore & $\begin{array}{l}\text { Miarasa, } \\
\text { Yagareba, Ai, } \\
\text { Weya, Orie, } \\
\text { Kaserai }\end{array}$ & 101 & 20 & $19 \cdot 8$ \\
\hline
\end{tabular}

Comparison of Standard, Reiter, and TPI test results

The results of the CWR, RPCF, VDRL, and TPI tests on the sera from each census unit are shown in detail in Table V (overleaf). As the TPI test is the most specific test for treponemal infection (Wilkinson and Rayner, 1966), the results of each of the other tests were compared with it. The VDRL test results showed closest agreement with the TPI test followed by the CWR and finally the RPCF test. Complete agreement between the VDRL and TPI test results occurred in only six census units. Only five units 
T A BL E I V Comparison of 1964 to 1965 and 1968 figures for prevalence of treponemal infection in language groups"studied

\begin{tabular}{|c|c|c|c|c|c|c|c|}
\hline \multirow{3}{*}{$\begin{array}{l}\text { Language } \\
\text { group }\end{array}$} & \multirow{3}{*}{ Census Unit } & \multicolumn{3}{|c|}{1964 to 1965} & \multicolumn{3}{|l|}{1968} \\
\hline & & \multirow{2}{*}{$\begin{array}{l}\text { No. of } \\
\text { sera } \\
\text { tested }\end{array}$} & \multicolumn{2}{|c|}{ TPI-reactive } & \multirow{2}{*}{$\begin{array}{l}\text { No. of } \\
\text { sera } \\
\text { tested }\end{array}$} & \multicolumn{2}{|c|}{ TPI-reactive } \\
\hline & & & No. & Per cent. & & No. & Per cent. \\
\hline Keigana & Afaru & 92 & 7 & $7 \cdot 6$ & 67 & 7 & $10 \cdot 4$ \\
\hline Auyana & Auyana & 72 & 57 & $79 \cdot 2$ & 74 & 35 & $47 \cdot 3$ \\
\hline North Fore & $\begin{array}{l}\text { Opoiyanti, } \\
\text { Keyonosa, } \\
\text { Okasa }\end{array}$ & 180 & 66 & 36.7 & 116 & 22 & $19 \cdot 0$ \\
\hline South Fore & $\begin{array}{l}\text { Miarasa, } \\
\text { Yagareba, } \\
\text { Ai }\end{array}$ & 330 & 110 & $33 \cdot 3$ & 80 & 18 & $22 \cdot 5$ \\
\hline
\end{tabular}

\begin{tabular}{|c|c|c|c|c|c|c|c|c|c|c|c|c|c|}
\hline \multirow{2}{*}{$\begin{array}{l}\text { Census Unit } \\
\text { Afaru }\end{array}$} & \multirow{2}{*}{$\begin{array}{l}\text { No. of } \\
\text { sera } \\
\text { tested }\end{array}$} & \multicolumn{12}{|c|}{ No. of reactive sera } \\
\hline & & 7 & 6 & 7 & 7 & 6 & - & 1 & 一 & - & - & - & - مू \\
\hline Auyana & 74 & 30 & 28 & 33 & 35 & 26 & - & 4 & - & 2 & - & 1 & 2 \\
\hline Mino & 81 & 2 & 2 & 3 & 3 & 2 & - & - & - & - & - & 1 & - \\
\hline Noveraisa & 40 & - & - & - & 1 & 一 & - & 一 & 一 & 一 & 一 & 一 & 1 \\
\hline $\begin{array}{l}\text { Misape, Ketabe, } \\
\text { Haiyuru, Takarie }\end{array}$ & 35 & 5 & 7 & 6 & 7 & 5 & $=$ & 一 & 一 & 1 & 1 & 一 & 一 \\
\hline Miarasa & 13 & 1 & 1 & 1 & 1 & 1 & - & 一 & 一 & 一 & 一 & - & $-\frac{I}{C}$ \\
\hline Yagareba & 28 & 1 & 1 & 1 & 1 & 1 & - & - & - & 一 & - & 一 & - \\
\hline $\mathbf{A i}$ & 39 & 10 & 12 & 12 & 16 & 8 & 1 & 1 & - & 3 & - & - & 3 \\
\hline $\begin{array}{l}\text { Weya, Orie, } \\
\text { Kaserai }\end{array}$ & 21 & 1 & 1 & 1 & 2 & 1 & - & - & - & - & - & - & 1 \\
\hline
\end{tabular}

showed complete agreement between the results of the CWR and TPI and four between the RPCF and TPI tests.

\section{Discussion}

From our investigation it appears that up to 1968 the treponemal disease which has been found among the inhabitants of the census units studied in the Eastern Highlands of New Guinea is yaws. No clinical evidence of active yaws was seen, though a few middle-aged persons showed signs of old yaws? lesions.

The prevalence of treponemal infection, as indicated by the TPI test results, was lower in $19688^{-}$ (18.1 per cent.) than in the group studied in 1964 to 65 ब (29.3 per cent.). This was to be expected as there were more children under 15 years of age and more females in the 1968 survey.

The children and females $(203+184=387)$ com- -8 prised 70.9 per cent. of the whole group in $1968 \mathrm{com}$ 
pared with 500 (59.2 per cent.) out of 844 of the 1964 to 65 group. This increase in the number of sera tested from children and females was intentional, because, as previously stated (Garner and Hornabrook 1968), our chief interest was in the children and serologically yaws-unprotected adult population. Another factor which might have played a part in the lower prevalence in the 1968 group was that many of those who were children in 1964 to 65 , and so belonged to the group with a low prevalence of treponemal infection, had become adults, i.e. 15 years of age or over, by 1968.

The prevalence of treponemal infection in the people studied in the Keigana and Gimi language groups was little altered in the 1968 from the 1964 to 65 survey, but that in the Auyana, North Fore, and South Fore language groups showed a marked fall in the number of sera found to be TPI reactive in 1968. This is probably a reflection of the larger number of children and females studied.

No clinical evidence of yaws was seen in the children under 15 years of age, although, as in the previous survey, serological evidence of treponemal infection was found. The fluorescent treponemal antibody absorption (FTA-ABS) test was the only test found to be reactive in the serum of one child, indicating the probability of an early treponemal infection. It is therefore reasonable to conclude that there were still some foci of active yaws, as yet undiscovered by us, in the communities studied. These had occurred despite the penicillin which had been widely given during various Kuru investigations over the past few years. To date no evidence exists to suggest that venereal syphilis has occurred in the yaws-unprotected population living in the area-no child was found to have congenital syphilis; nor were any signs of neurosyphilis detected. These people come from a primitive way of life, with gradually increasing contact with Europeans, in a rapidly developing country.

\section{Summary}

Serological tests for treponemal infection were carried out in 1968 among the inhabitants of eighteen census units in the Eastern Highlands of New Guinea. Ten of the census units had been previously studied in 1964 to 65 . As well as routine serological tests a TPI test was performed on each serum, its results being taken to indicate the presence or absence of treponemal infection in the individual. Clinically no cases of active yaws were seen, though some middleaged persons showed signs of old yaws infection.

The prevalence of treponemal infection varied in the census units studied from 2.5 to 47.3 per cent., males having a higher prevalence than females. Serological evidence of treponemal infection, as indicated by the TPI test results, was found in 3.9 per cent. of the children under 15 years of age. As in the 1964 to 65 survey it was concluded that the treponemal disease involved was yaws. Future investigations of these people are planned, our main interest being those with no relative cross-immunity from yaws against venereal syphilis.

We should like to thank Miss J. Backhouse, Miss C. Collins, and Mrs. P. Roeder for their technical assistance, and the World Health Organization for permission to use the map in the text.

\section{References}

GaRner, M. F., and HoRNABrooK, R. W. (1968) Bull. Wld Hlth Org., 38, 189

GuTHE, T., and DE VRIES, J. L. (1966) Unpublished working document, W.H.O.

Wilkinson, A. E., and Rayner, C. F. A. (1966) Brit. F. vener. Dis., 42, 8

Enquête sur les tréponématoses dans les hautes terres de la Nouvelle Guinée Orientale en 1968

SOMMAIRE

En 1968, des tests sérologiques pour détecter l'infection tréponémique furent effectués dans la population de dix-huit unités de recensement dans les Hautes Terres de la Nouvelle Guinée Orientale. Dix de ces unités avaient déjà été étudiées en 1964 et 1965 . A côté des épreuves sérologiques courantes, le TPI fut effectué sur chaque sérum, son résultat étant accepté comme indiquant la présence ou l'absence d'infection tréponémique chez le sujet considéré. Cliniquement, il ne fut observé aucun cas de pian actif, quoique quelques personnes d'âge moyen présentaient des signes d'infection pianique ancienne.

Selon les unités de recensement étudiées, la prévalence de l'infection tréponémique allait de 2,5 à 47,3 pour cent, cette prévalence étant plus élevée chez les hommes que chez les femmes. La preuve sérologique d'une infection tréponémique telle que l'indiquait le résultat du TPI fut fournie pour 3,9 pour cent des enfants de moins de quinze ans. Comme dans l'enquête de 1964-1965, la conclusion fut que l'infection tréponémique responsable était le pian. Nous nous proposons des récherches ultérieures dans cette population, notre intérêt principal portant sur les sujets qui n'ont pas d'immunité croisée relative due au pian vis-à-vis de la syphilis vénérienne. 